\title{
Development of multiplex PCR to detect slow rust resistance genes Lr34 and Lr46 in wheat
}

\author{
Roksana Skowrońska $^{1}$ (D) - Michał Kwiatek ${ }^{1}$ (D) - Agnieszka Tomkowiak ${ }^{1}$ (D) · Jerzy Nawracała ${ }^{1}$ (D)
}

Received: 20 March 2019 /Revised: 15 July 2019 / Accepted: 3 September 2019 / Published online: 10 September 2019

(C) The Author(s) 2019

\begin{abstract}
Leaf rust caused by Puccinia triticina belongs to one of the most dangerous fungal diseases of wheat (Triticum aestivum L.) and is the cause of large yield losses every year. Here we report a multiplex polymerase chain reaction (PCR) assay, which was developed for detection of two important wheat slow rust resistance genes $\operatorname{Lr} 34$ and $L r 46$, using two molecular markers: $\operatorname{csLV34}$ and Xwmc44, respectively. The presence of genes was analyzed in one winter wheat variety TX89D6435 and five spring wheat varieties: Pavon F76, Parula 'S', Rayon 89, Kern, Mochis 88. Both $L r 34$ and $L r 46$ genes were identified in variety TX89D6435, gene $L r 34$ was also identified in Parula ' $\mathrm{S}$ ' and Kern varieties, and gene $L 46$ occurs in Pavon F76 and Mochis 88 variety. None of the resistance genes tested was detected in the Rayon 89 variety. The use of the multiplex PCR method allowed to shorten the analysis time, reduce costs of analyses, and reduce the workload.
\end{abstract}

Keywords Leaf rust $\cdot \operatorname{Lr} 34 \cdot \mathrm{Lr} 46 \cdot$ Multiplex PCR $\cdot$ Wheat

\section{Introduction}

Leaf rust caused by the pathogen Puccinia triticina Erikss. \& Henn. is one of the most destructive diseases of wheat (Kolmer et al. 2005). There are many fungicides that help control these fungal disease, but their use is expensive and can have a negative impact on the environment. The most efficient, economical, and environmentally sound method to mitigate the losses caused by pathogens is breeding for genetic resistance (Muthe et al. 2016). To date, more than 70 leaf rust resistance $(L r)$ genes have been cataloged (McIntosh et al. 2013), but many of these genes are race-specific and they have lose their effectiveness when new races of the pathogen are appearing (McCallum et al. 2007). Currently, breeding programs focus on producing cultivars with adult plant resistance (APR), also known as slow rusting or race non-specific genes. Slow rusting genes are a group of leaf rust resistance genes

Communicated by: Barbara Naganowska

Michał Kwiatek

michal.kwiatek@up.poznan.pl

1 Department of Genetics and Plant Breeding, Faculty of Agronomy and Bioengineering, Poznań University of Life Sciences, 11 Dojazd Str, 60-632 Poznań, Poland that give durable resistance only in adult plant (Bošković et al. 2008). APR is characterized by less and slower pathogen growth and reproduction despite a high infection type (Tiwari et al. 2009). An important advantage of genes is their pleiotropic effect on many pathogens, for example Blumeria graminis causing powdery mildew (Lillemo et al. 2008). Among all, the leaf rust resistance genes in wheat only four genes are known as slow rusting: Lr34 (Singh 1992), Lr46 (Singh et al. 1998), Lr67 (Dyck and Samborski 1979), and Lr68 (Herrera-Foessel et al. 2012).

The leaf rust resistance gene $\operatorname{Lr} 34$ (earlier $L r T 2$ ) is the best known and most effective of slow rusting genes. The gene Lr34 was first described in the wheat line PI58548 and located on short arm of wheat chromosome 7D (Dyck 1987). Lagudah et al. (2006) developed PCR-based marker csLV34 that has been used extensively to identify the presence of $L r 34$ gene. The disadvantage is that the marker is not diagnostic in some genetic backgrounds, like Canadian wheat germplasm (Lagudah et al. 2009). Leaf tip necrosis (LTN) is one of the morphological markers associated with leaf rust resistance gene $\operatorname{Lr} 34$ and is also expressed in the absence of the pathogen (Lagudah et al. 2006). The $\mathrm{Lr} 46$ gene was first described in wheat cultivar Pavon F76 and was localized on chromosome 1BL (Singh et al. 1998). Lr46 shows a resistance phenotype in adult plants similar to $L r 34$, but the effects of $L r 46$ are not as pronounced as Lr34 (Martinez et al. 2001). Lillemo et al. 
(2008) have shown that $L r 46$ has an additive effect on leaf rust resistance of $L r 34$. The gene $L r 46$ was mapped distal to Xwmc44 and proximal to Xgwm259 (Suenaga et al. 2003).

\section{Material and methods}

The aim of this study was to develop a multiplex PCR method for simultaneous identification of two most effective slow rust resistance genes: Lr34 and Lr46. Plant material consisted of six wheat cultivars Triticum aestivum L. derived from the National Small Grains Collection, the Agriculture Research Station in Aberdeen, USA: TX89D6435, Pavon F76, Parula 'S', Rayon 89, Kern and Mochis 88 (Table 1).

The DNA was extracted from leaf tissue using the GeneMATRIX Plant \& Fungi DNA Purification Kit (EURx Ltd., Poland). DNA quality and concentration was checked using the DeNovix spectrophotometer. In order to identify the $L r 34$ and $L r 46$ genes, two molecular markers were used: $c s L v 34$ and Xwmc44. The STS marker $c s L V 34$ maps $0.4 \mathrm{cM}$ from $L r 34$ and the sequence of primers (Merck) is as follows: csLV34F 5'- GTT GGT TAA GAC TGG TGA TGG -3'; csLV34R 5'- TGC TTG CTA TTG CTG AAT AGT -3' (Lagudah et al. 2006). According to the literature, the size of the amplified product is a $150 \mathrm{bp}$ (base pairs) band, indicative of the presence of the gene and a $229 \mathrm{bp}$ band in susceptible genotypes. Locus of SSR marker Xwmc44 is located $0.4 \mathrm{~cm}$ from QTL for $L r 46$. A product of the microsatellite marker is $242 \mathrm{bp}$ band for the presence of $L r 46$ gene, and the sequence of marker primers is as follows: WMC44F 5'- GGT CTT CTG GGC TTT GAT CCT G -3', WMC44R 5'- GTT GCT AGG GAC CCG TAG TGG -3' (Suenaga et al. 2003). The $25 \mu \mathrm{L}$ mix composition of multiplex PCR volume consisted of the following: $12.5 \mu \mathrm{L} 2 \times$ PCR TaqNovaHs PCR Master Mix (Blirt), which included $2 \times$ concentrated $\mathrm{PCR}$ reaction buffer, $4 \mathrm{mM} \mathrm{MgCl} 2 ; 1.6 \mathrm{mM}$ dNTPs mix ( $0.4 \mathrm{mM}$ of each dNTP); $0.8 \mu \mathrm{L} c s L v 34$ forward primer; $0.8 \mu \mathrm{L} c s L v 34$ reverse primer;

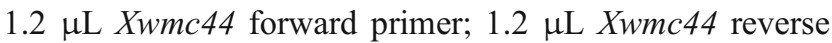
primer (the concentration for each primer was $100 \mu \mathrm{M}$ ); $2 \mu \mathrm{L}$ DNA template $(50 \mathrm{ng} / \mu \mathrm{L})$ and $6.5 \mu \mathrm{L}$ PCR grade water. PCR profile was modified with reference to standard protocol. The following annealing temperatures were tested: $55^{\circ} \mathrm{C}$, optimal for the $c s L v 34$ primer (Lagudah et al. 2006), $61{ }^{\circ} \mathrm{C}$ recommended for the Xwmc44 marker (Suenaga et al. 2003), and several intermediate variants. The final PCR reaction consisted of initial denaturation at $94{ }^{\circ} \mathrm{C}$ for $5 \mathrm{~min}$, followed by 40 cycles (denaturation, $94^{\circ} \mathrm{C}$ for $45 \mathrm{~s}$; primer annealing, $60{ }^{\circ} \mathrm{C}$ for $30 \mathrm{~s}$; elongation, $72{ }^{\circ} \mathrm{C}$ for $1 \mathrm{~min}$ ), followed by the final extension for $7 \mathrm{~min}$ at $72{ }^{\circ} \mathrm{C}$ and final step at $4{ }^{\circ} \mathrm{C}$. The reaction was carried out using the Labcycler thermal cyclers (SensoQuest $\mathrm{GmbH}$ ). The products of amplification were prepared by adding 0.5 Midori Green Direct (NIPPON Genetics EUROPE) to each tube and were separated using $2 \%$ agarose (SIGMA) gel in $1 \times$ TBE buffer (BioShop) at $100 \mathrm{~V}$ for two and a half hours. A Molecular Imager Gel Doc ${ }^{\mathrm{TM}}$ XR UV system was used with the Biorad Bio Image ${ }^{\mathrm{TM}}$ Software to visualize the PCR products.

\section{Results and discussion}

Molecular markers can be successfully used in the identification of leaf rust resistance genes in wheat resistance breeding programs (Vida et al. 2009). The results showed that the amplification of csLv34 marker was observed in TX89D6435, Parula 'S', and Kern varieties, but the size of the resulting Lr34 gene linked product was approximately $145 \mathrm{bp}$, which is smaller than reported by Lagudah et al. (2006). Differences in the size of products may result from the size of the DNA ladder used. Lagudah et al. (2006) used a 100 bp ladder molecular size markers. In our experiment we have used more precise, 50 bp DNA ladder, which showed that the csLv34 marker product is smaller than $150 \mathrm{bp}$. Considering other varieties (Pavon F76, Rayon 89, and Kern') the PCR reaction with $c s L v 34$ marker showed a 229 bp product, indicating the lack of the $L r 34$ gene. The analyses with the Xwmc 44 marker linked to the $L r 46$ gene resulted in the identification of a 242 bp specific product in TX89D6435, Pavon F76, and Mochis 88 varieties. The accumulation of both $L r 34$ and Lr46 resistance genes was demonstrated by the multiplex PCR in TX89D6435 variety, so this variety can be a good source of non-race specific resistance to leaf rust (Table 1, Fig. 1).

Table 1 Presence of genes $L r 34$ and $L 46$ in tested wheat varieties

\begin{tabular}{llllll}
\hline No. & Cultivar & Origin & Plant ID & Presence of Lr34 & Presence of Lr46 \\
\hline 1. & TX89D6435 & US, Texas & PI 584759 & + & + \\
2. & Pavon F76 & Mexico & PI 520003 & - & + \\
3. & Parula 'S' & Mexico & PI 520340 & + & - \\
4. & Rayon 89 & Mexico & PI 591784 & - & - \\
5. & Kern & US & PI 672001 & + & + \\
6. & Mochis 88 & Mexico & PI 591791 & - \\
\hline
\end{tabular}




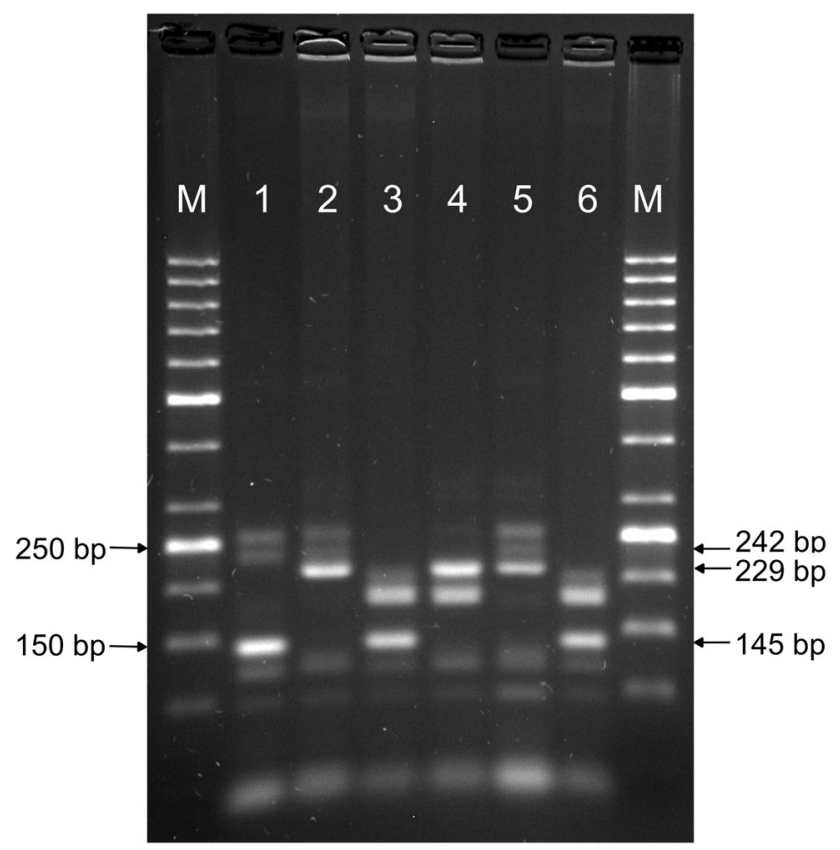

Fig. 1 Electrophoresis showing the presence of markers: $\operatorname{csLv} 34$ (for the Lr34) and Xwmc44 (for the Lr46) in the wheat varieties. M, GeneRuler 50 bp DNA ladder (NIPPON Genetics EUROPE GmbH); 1 , TX89D6435; 2, Pavon F76; 3, Parula 'S'; 4, Rayon 89; 5, Kern; 6, Mochis 88

The literature gives many examples of successful use of the multiplex PCR method to identify race-specific resistance genes. Leśniowska-Nowak et al. (2013) developed a multiplex PCR method to identify two resistance genes for leaf rust $L r 9$ and $L r 19$. Other major resistance genes for P. triticina $L r 29$ and $L r 37$ were identified with one PCR reaction by Sumikova and Hanzalova (2010). Gogół et al. (2015) made a successful attempt to use the multiplex PCR method to simultaneously identify genes of resistance to two different diseases: $\operatorname{Lr} 21$ (leaf rust) and $P m 4 b$ (powdery mildew). Tomkowiak et al. (2019) identified the Pm2, Pm3a, Pm4b, and $P m 6$ genes and developed multiplex PCR reaction conditions for simultaneous identification of $P m 2$ and $P m 4 b$ genes.

Slow rusting genes $L r 34$ and $L r 46$ are very important for breeding because they provide durable resistance over a long period of time in different environments, and they are effective against many pathogens (Imbaby et al. 2014). The development of the multiplex PCR method allows to significantly shorten the time of analysis of these two important genes. The study demonstrated that the developed multiplex PCR conditions are effective diagnostic tool for the simultaneous identification of $\operatorname{Lr} 34$ and $L 46$ genes using the $\operatorname{csLv} 34$ and Xwmc 44 markers, respectively. The developed multiplex PCR conditions can be used in breeding programs for marker-assisted selection.

Acknowledgments The authors would like to acknowledge and thank Dr. Harrold Bockelman at the USDA/ARS Small Grains Laboratory, Aberdeen (ID, USA), for providing the seeds samples.
Authors contribution statement RS made the experiments and analyses, wrote the first draft, and incorporated all inputs from co-authors. MK initiated the project. MK, AT, and JN revised the draft and made suggestions for improving the manuscript.

\section{Compliance with ethical standards}

Conflict of interest The authors declare that they have no conflict of interests.

Open Access This article is distributed under the terms of the Creative Commons Attribution 4.0 International License (http:// creativecommons.org/licenses/by/4.0/), which permits unrestricted use, distribution, and reproduction in any medium, provided you give appropriate credit to the original author(s) and the source, provide a link to the Creative Commons license, and indicate if changes were made.

\section{References}

Bošković J, Bošković M, Prijić Ž (2008) Accumulations of genes for durable resistance to wheat leaf rust pathogen. J Agric Sci 53(3): 163-172. https://doi.org/10.2298/JAS0803163B

Dyck PL (1987) The association of a gene for leaf rust resistance with the chromosome 7D suppressor of stem rust resistance in common wheat. Genome. 29(3):467-469. https://doi.org/10.1139/g87-081

Dyck PL, Samborski DJ (1979) Adult-plant leaf rust resistance in PI 250413, an introduction of common wheat. Can J Plant Sci 59(2): 329-332. https://doi.org/10.4141/cjps79-053

Gogół A, Leśniowska-Nowak J, Nowak M, Okoń S, Kowalczyk K (2015) Development of multiplex PCR for $L r 21$ and Pm $4 b$ resistance genes detection in common wheat (Triticum aestivum L.). Ann UMCS Sectio E LXX(3):21-30

Herrera-Foessel SA, Singh RP, Huerta-Espino J, Rosewarne GM, Periyannan SK, Viccars L, Calvo-Salazar V, Lan C, Lagudah ES (2012) Lr68: a new gene conferring slow rusting resistance to leaf rust in wheat. Theor Appl Genet 124(8):1475-1486. https://doi.org/ 10.1007/s00122-012-1802-1

Imbaby IA, Mahmoud MA, Hassan MEM, Abdel-aziz ARM (2014) Identification of leaf rust resistance genes in selected Egyptian wheat cultivars by molecular markers. Sci World J 7. https://doi.org/10. $1155 / 2014 / 574285$

Kolmer JA, Long DL, Hughes ME (2005) Physiologic specialization of Puccinia triticina on wheat in the United States in 2003. Plant Dis 89(11):1201-1206. https://doi.org/10.1094/PD-89-1201

Lagudah ES, McFadden H, Singh RP, Huerta-Espino J, Bariana HS, Spielmeyer W (2006) Molecular genetic characterization of the Lr34/Yr18 slow rusting resistance gene region in wheat. Theor Appl Genet 114(1):21-30. https://doi.org/10.1007/s00122-0060406-Z

Lagudah ES, Krattinger SG, Herrera-Foessel S, Singh RP, Huerta-Espino J, Spielmeyer W, Brown-Guedira G, Selter LL, Keller B (2009) Gene-specific markers for the wheat gene Lr34/Yr18/Pm38 which confers resistance to multiple fungal pathogens. Theor Appl Genet 119(5):889-898. https://doi.org/10.1007/s00122-009-1097-z

Leśniowska-Nowak J, Gradzielewska A, Majek M (2013) Identification of the gene resistant to leaf rust in selected European wheat cultivars and multiplex PCR development. Ann UMCS Sect E 68(3):20-28

Lillemo M, Asalf B, Singh RP, Huerta-Espino J, Chen XM, He ZH, Bjørnstad $\AA$ (2008) The adult plant rust resistance loci $\operatorname{Lr} 34 / \mathrm{Yr} 18$ and $L r 46 / Y r 29$ are important determinants of partial resistance to 
powdery mildew in bread wheat line Saar. Theor Appl Genet 116(8): 1155-1166. https://doi.org/10.1007/s00122-008-0743-1

Martinez F, Niks RE, Singh RP, Rubiales D (2001) Characterization of Lr46, a gene conferring partial resistance to wheat leaf rust. Hereditas. 135(23):111-114. https://doi.org/10.1111/j.1601-5223. 2001.00111.x

McCallum BD, Fetch T, Chong J (2007) Cereal rust control in Canada. Aust J Agric Res 58:639-647. https://doi.org/10.1016/S10068104(12)60032-4Get

McIntosh RA, Yamazaki Y, Dubcovsky J, Rogers WJ, Morris C, Appels R, Xia XC (2013) Catalogue of gene symbols for wheat: 12th International Wheat Genetics Symposium, 8-13 September 2013, Yokohama, Japan

Muthe ST, Kulwal PL, Gadekar DA, Jadhav AS (2016) Molecular marker based detection of leaf rust resistance gene Lr34 in Indian bread wheat (Triticum aestivum L.). Australas Plant Pathol 45(4):369 376. https://doi.org/10.1007/s13313-016-0423-6

Singh RP (1992) Expression of wheat leaf rust resistance gene Lr34 in seedlings and adult plants. Plant Dis 76:489-491

Singh RP, Mujeeb-Kazi A, Huerta-Espino J (1998) Lr46: a gene conferring slow-rusting resistance to leaf rust in wheat. Phytopathology. 88(9):890-894. https://doi.org/10.1094/PHYTO.1998.88.9.890

Suenaga K, Singh RP, Huerta-Espino J, William HM (2003) Microsatellite markers for genes $\operatorname{Lr} 34 / \mathrm{Yr} 18$ and other quantitative trait loci for leaf rust and stripe rust resistance in bread wheat. Phytopathology. 93(7):881-890. https://doi.org/10.1094/PHYTO. 2003.93.7.881

Sumikova T, Hanzalova A (2010) Multiplex PCR assay to detect rust resistance genes $\operatorname{Lr} 26$ and $\operatorname{Lr} 37$ in wheat. Czech J Genet Plant 46(2):85-89. https://doi.org/10.17221/32/2010-CJGPB

Tiwari R, Saharan MS, Chatrath R, Siwach P, Mishra B (2009) STS marker based tracking of slow rusting $\mathrm{Lr} 34$ gene in Indian wheat genotypes. Indian J Biotechnol 8:207-213

Tomkowiak A, Skowrońska R, Weigt D, Kwiatek M, Nawracała J, Kowalczewski PŁ, Pluta M (2019) Identification of powdery mildew Blumeria graminis f. sp. tritici resistance genes in selected wheat varieties and development of multiplex PCR. Open Chem 17:157-165. https://doi.org/10.1515/chem-2019-0024

Vida G, Gál M, Uhrin A, Veisz O, Syed NH, Flavell AJ, Wang Z, Bedo Z (2009) Molecular markers for the identification of resistance genes and marker-assisted selection in breeding wheat for leaf rust resistance. Euphytica 170:67-74. https://doi.org/10.1007/s10681-0099945-0

Publisher's note Springer Nature remains neutral with regard to jurisdictional claims in published maps and institutional affiliations. 